\begin{tabular}{c} 
International Journal of Advanced Chemistry, 2(2)(2014) 66-69 \\
International Journal of Advanced Chemistry \\
Journal home page: $\begin{array}{c}\text { www.sciencepubco.com/index.php/IJAC } \\
\text { doi: } 10.14419 / \text { ijac.v2i2.2114 } \\
\text { Research Paper }\end{array}$ \\
\hline
\end{tabular}

\title{
Acoustic and volumetric properties of aqueous solution of levofloxacin nickel complexes at 308K
}

\author{
Monalisa Das ${ }^{1}$, Smrutiprava Das ${ }^{1}$, Ajaya Kumar Patnaik ${ }^{2}$ \\ ${ }^{1}$ PG Department of Chemistry, Raven Shaw University, Cuttack \\ ${ }^{2}$ P. G. Department of Chemistry, Raven Shaw University, Cuttack-753003, Odisha, India \\ *Corresponding author E-mail: dassmrutiprava@yahoo.in
}

\begin{abstract}
The density and ultrasonic velocity were measured for aqueous solutions of nickel complex and its ternary complex with 1,10 phenanthroline at $308 \mathrm{~K}$. Using the experimental data, adiabatic compressibility, acoustic impedance , intermolecular free length and hydration number, apparent molar volume , limiting apparent molar volume, apparent molar compressibility, limiting apparent molar compressibility and their associated constants were calculated. These parameters were used to study the ion-solvent interaction in each solution.
\end{abstract}

Keywords: Ultrasonic Velocity, Hydration Number, Adiabatic Compressibility, Apparent Molar Volume, Apparent Molar Compressibility.

\section{Introduction}

Ultrasonic investigation in aqueous solutions of electrolytes and non-electrolytes provides useful information in understanding the degree and nature of interaction because intra molecular and intermolecular association related structural changes affect the ultrasonic velocity. By ultrasonic measurements, the molecular interactions in pure liquids ${ }^{1-4}$, aqueous solution ${ }^{5-7}$ and liquid mixtures ${ }^{8-11}$ have also been studied. Iqbal et al ${ }^{12}$ have studied the apparent molar volume and adiabatic compressibility of aqueous solutions of drugs such as sodium salicylate, methyl orange, L-tryptophan, phenol and hydrochloride salts of procaine and pilocarpene and ephedrine. Naidu et al ${ }^{13}$ have reported the ultrasonic velocity; density and viscosity studies in aqueous solution of levofloxacin hemi hydrates, tacrolimus monohydrate and lisinopril dehydrate. The interaction between oral levofloxacin and multivalent cations has been described by pharmacokinetic studies ${ }^{14}$.

In the present paper levofloxacin is selected for the study as it is effective against diarrhea caused by Escherichia Coli, campylobacter Jejune and shigella bacteria. It is used for testing infections of the sinuses, skin, lungs, ears, airways, bones and joints caused by susceptible bacteria. It is also used to treat urinal infections. It has been reported ${ }^{15-18}$ that the levofloxacin (quinolones) act as a monoionic bidentate ligand through their carboxylate and carbonyl groups. The interaction between quinolone and metal cations was based on chelation. Since the functional groups like carbonyl and carboxyl groups are required for antibacterial activity, it could be anticipated that all the quinolones could be interacting with metal ions ${ }^{19}$. The density and partial molar volume measurements of aqua-organic liquids at infinite dilution ${ }^{20}$ have been found to be highly useful in understanding the structure of molecular interaction between water and organic molecules. However there are rare reports on acoustic behaviour of metal complexes of drugs. The present paper represents the acoustical and volumetric proper ties of nickel complexes of levofloxacin and its ternary complex with 1, 10-phenanthroline at $308 \mathrm{~K}$.

\section{Experimental}

The hydrated salt $\mathrm{NiCl}_{2} \cdot 6 \mathrm{H}_{2} \mathrm{O}$ was Anal $\mathrm{R}$ grade. Levofloxacin were obtained from a local pharmaceutical company. Water used in this study was doubled distilled water prepared by distilling water over alkaline potassium permanganate in all glass distillation flasks. All the complexes were prepared from reported methods $^{21}$. These complexes were characterized by elemental analysis and spectroscopic methods. The ultrasonic velocity was measured by single crystal interferometer (Mittal, model-81) operating at a frequency of $2 \mathrm{MHz}$. The temperature was maintained constant at $308.05 \mathrm{~K}$ in a thermostat. The density of solutions was determined accurately using specific gravity bottle and electronic balance of accuracy $( \pm 0.1 \mathrm{mg})$.

\section{Result and discussion}

The desired parameters such as adiabatic compressibility $(\beta)$, inter molecular free length $\left(L_{f}\right)$, acoustic impedance $(Z)$, hydration number $\left(n_{H}\right)$, limiting apparent molar compressibility $\left(K_{\varphi}\right)$, apparent molar volume $\left(V_{\varphi}\right)$, limiting apparent molar compressibility $\left(K_{\varphi}^{0}\right)$, limiting apparent molar volume $\left(V_{\varphi}^{0}\right)$ and their constants $\left(S_{k}\right.$ and $S_{v}$ ) had been studied at $308 \mathrm{~K}$. Density is known to be a measure of ion-solvent and solvent-solvent interactions. The ultrasonic velocity ${ }^{22-23}$, adiabatic compressibility, acoustic impedance, intermolecular free length and hydration number ${ }^{24}$ calculated with equations (1)-(4) are given as,

$$
\begin{aligned}
& U=(\beta d)^{-1 / 2} \\
& \beta=d^{-1} U^{-2}
\end{aligned}
$$




$$
\begin{aligned}
& Z=U d \\
& L_{f}=K_{j} \beta^{1 / 2} \\
& n_{H}=\frac{n_{1}}{n_{2}}\left[1-\left(\beta-\beta^{0}\right)\right]
\end{aligned}
$$

Where $U, \beta, d, Z, L_{f}$ and $n_{H}$ are the ultrasonic velocity, adiabatic compressibility, density, acoustic impendance, intermolecular free length and hydration number respectively. $\beta^{0}$ Is the adiabatic compressibility of the solvent. $K_{j}$ Is Jacobson constant = $2.0965 \times 10^{-6}$

From the density data, the apparent molar volume $\left(V_{\varphi}\right)$ was calculated from the relation of the type Harned and Owen ${ }^{25}$ :

$V_{\varphi}=1000\left(c d_{0}\right)^{-1}\left(d_{0}-d\right)+M_{2} d_{0}^{-1}$

Where $c$ the molar concentration of the solution is, $M_{2}$ is the molecular mass of the solute, $d_{0}$ and $d$ are the densities of pure solvent and solution respectively.
The $V_{\varphi}$ data were fitted with an equation of the type Masson ${ }^{26}$,

$V_{\varphi}=V_{\varphi}^{0}+S_{v} c^{1 / 2}$

The apparent molar compressibility, $K_{\varphi}$ can be computed from the equation 27

$K_{\varphi}=1000 \beta c^{-1}-\beta^{0} d^{-1}\left(1000 c^{-1}-M_{2}\right)$

$K_{\varphi}$ Is the function of $c$ as obtained by Gucker[27] from Debye Huckel theory ${ }^{28}$ and is given by,

$K_{\varphi}=K_{\varphi}^{0}+S_{k} c^{1 / 2}$

$K_{\varphi}^{0}$ Is the apparent molar compressibility and $S_{k}$ is the slope.

The value of density, Ultrasonic velocity, adiabatic compressibility, acoustic impedance, intermolecular free length and hydration number of both the nickel complexes were listed in Table 1.

\begin{tabular}{|c|c|c|c|c|c|c|}
\hline $\begin{array}{l}\text { Concentration }(c) \\
\text { moldm }^{-3}\end{array}$ & $\begin{array}{l}\operatorname{Density}(d) \\
\times 10^{3} \mathrm{kgm}^{-3}\end{array}$ & $\begin{array}{l}\text { Ultrasonic veloci- } \\
\text { ty }(U) \mathrm{msec}^{-1}\end{array}$ & $\begin{array}{l}\text { Adiabatic compressibil- } \\
\text { ity }(\beta) \times 10^{-7} \mathrm{~m}^{2} \mathrm{~N}^{-1}\end{array}$ & $\begin{array}{l}\text { Acoustic Imped- } \\
\text { ance }(Z) \times 10^{-3} \\
\mathrm{~kg} \mathrm{~m}^{2} \mathrm{~s}^{-1}\end{array}$ & $\begin{array}{l}\text { Intermolecular free } \\
\text { length }\left(L_{f}\right) \times 10^{-9} \\
\mathrm{~m}\end{array}$ & $\begin{array}{l}\text { hydration num- } \\
\text { ber }\left(n_{H}\right)\end{array}$ \\
\hline \multicolumn{7}{|c|}{$\left[\mathrm{Ni}(\text { levo })_{2}\left(\mathrm{H}_{2} \mathrm{O}\right)_{2}\right] 2 \mathrm{H}_{2} \mathrm{O}$} \\
\hline 0.0099 & 997.71 & 1508.0 & 4.4076 & 1504.5 & 1.3919 & 6.6321 \\
\hline 0.0196 & 996.90 & 1509.2 & 4.4085 & 1503.0 & 1.3920 & 2.7584 \\
\hline 0.0291 & 994.51 & 1510.3 & 4.4105 & 1501.2 & 1.3923 & 1.0011 \\
\hline 0.0385 & 992.17 & 1511.4 & 4.4125 & 1499.5 & 1.3926 & 0.1253 \\
\hline \multicolumn{7}{|c|}{ [Ni (levo) $(1,10$-phenanthroline $)] \mathrm{Cl}$} \\
\hline 0.0099 & 1000.4 & 1510.2 & 4.3829 & 1537.5 & 1.3881 & 37.5399 \\
\hline 0.0197 & 998.80 & 1511.5 & 4.3823 & 1532.1 & 1.3879 & 42.1377 \\
\hline 0.0284 & 996.74 & 1512.8 & 4.3336 & 1510.8 & 1.3649 & 52.7806 \\
\hline 0.0388 & 994.96 & 1540.1 & 4.2382 & 1509.7 & 1.3576 & 54.7066 \\
\hline 0.0481 & 991.29 & 1551.1 & 4.1933 & 1507.9 & 1.3380 & 54.9585 \\
\hline
\end{tabular}

Table 1: The Values of Density $(d)$, Ultrasonic Velocity $(U)$, Adiabatic Compressibility $(\beta)$, Acoustic Impedance $(Z)$, Intermolecular Free length $\left(L_{f}\right)$ and Hydration number $\left(n_{H}\right)$ of $\left[\mathrm{Ni}(\text { Levo })_{2}\left(\mathrm{H}_{2} \mathrm{O}\right)_{2}\right] 2 \mathrm{H}_{2} \mathrm{O}$ and $[\mathrm{Ni}($ Levo $)(1,10$-Phenanthroline $)] \mathrm{Cl}$ Complexes in Water At $308 \mathrm{~K}$.

The density was found to decrease for both the nickel complexes with increase in concentration. Decrease in density indicated the decrease in solvent-solvent or ion-solvent or structure breaking property of metal complexes. The variation of ultrasonic velocity with molar concentration was shown by Figure 1.

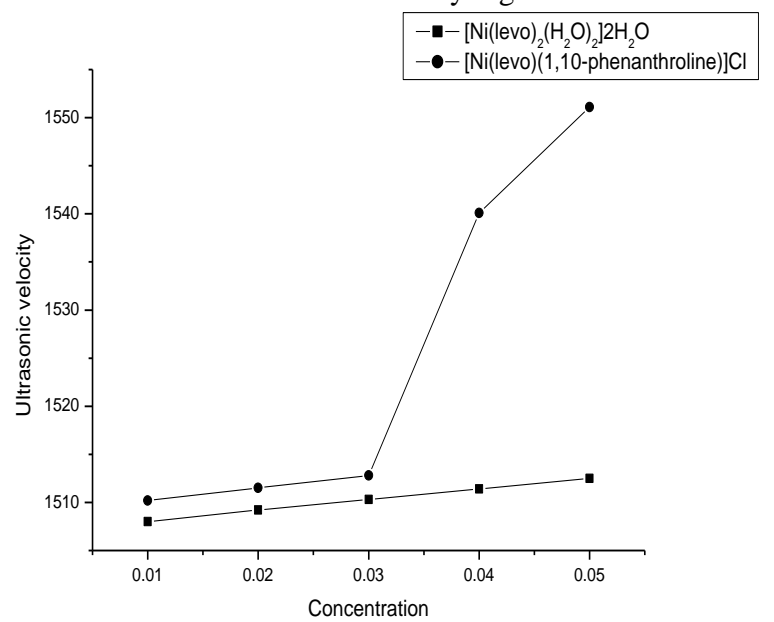

Fig. 1: Variation of Ultrasonic Velocity $(U)$ with Concentration for $\left[\mathrm{Ni}(\text { Levo })_{2}\left(\mathrm{H}_{2} \mathrm{O}\right)_{2}\right] 2 \mathrm{H}_{2} \mathrm{O}$ and $[\mathrm{Ni}($ Levo $)(1,10-\mathrm{Phenanthroline})] \mathrm{Cl}$ Complexes At $308 \mathrm{~K}$.

The ultrasonic velocity increased smoothly with concentration in [Ni (levo) $\left.{ }_{2}\left(\mathrm{H}_{2} \mathrm{O}\right)_{2}\right] 2 \mathrm{H}_{2} \mathrm{O}$. But increase in ultrasonic velocity occurred steadily in case of [Ni (levo) (1, 10-phenanthroline)] $\mathrm{Cl}$. The increase in ultrasonic velocity for both the nickel complexes may be due to molecular association caused by cohesive forces ${ }^{29}$.
The adiabatic compressibility $(\beta)$ is a measure of intermolecular association or repulsion calculated from the measured ultrasonic velocity $(U)$ and density $(d)$. The $\beta$ values were found to increase in $\left[\mathrm{Ni}(\text { levo })_{2}\left(\mathrm{H}_{2} \mathrm{O}\right)_{2}\right] 2 \mathrm{H}_{2} \mathrm{O}$ and decrease in $[\mathrm{Ni}($ levo $)(1,10$ phenanthroline) $\mathrm{Cl}$ (Figure 2).

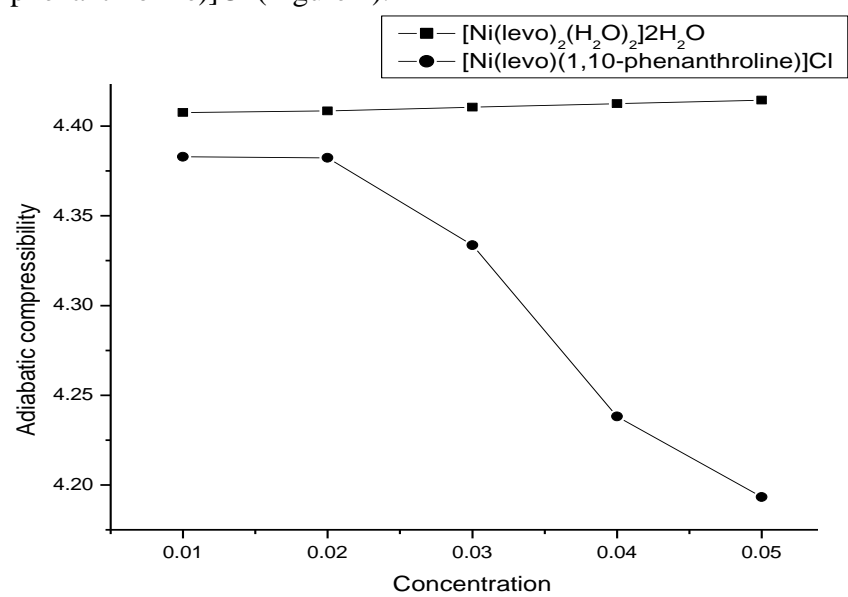

Fig. 2: Variation of Adiabatic Compressibility $(\beta)$ with Concentration for $\left[\mathrm{Ni}(\text { Levo })_{2}\left(\mathrm{H}_{2} \mathrm{O}\right)_{2}\right] 2 \mathrm{~h}_{2} \mathrm{O}$ and $[\mathrm{Ni}($ Levo $)(1,10$-Phenanthroline $)] \mathrm{Cl}$ Complexes At $308 \mathrm{k}$.

Decrease in adiabatic compressibility in $[\mathrm{Ni}$ (levo) (1, 10phenanthroline)] $\mathrm{Cl}$ might be due to close association between water molecules i.e. solvent-solvent interaction and also electrostriction $^{30}$. The increase in $\beta$ values for [Ni (levo $\left.)_{2}\left(\mathrm{H}_{2} \mathrm{O}\right)_{2}\right] 2 \mathrm{H}_{2} \mathrm{O}$ complex with increase in concentration of solution may be due to 
collection of water molecules around ions ${ }^{31}$. This implies significant solute-solvent interaction in $\left[\mathrm{Ni}(\mathrm{levo})_{2}\left(\mathrm{H}_{2} \mathrm{O}\right)_{2}\right] 2 \mathrm{H}_{2} \mathrm{O}$.

The value of acoustic impedance $(Z)$ decreased with increase in concentration for both the complexes in water. When concentration of solute increases, the thickness of oppositely charged ionic atmosphere may increase due to decrease in ionic strength. This is suggested by decrease in acoustic impedance with increase in concentration in both the systems investigated.

It was found that intermolecular free length increased on increasing the concentration of $\left[\mathrm{Ni}(\mathrm{levo})_{2}\left(\mathrm{H}_{2} \mathrm{O}\right)_{2}\right] 2 \mathrm{H}_{2} \mathrm{O}$ and decreased in [Ni (levo) (1, 10-phenanthroline)] $\mathrm{Cl}$. The increase in $L_{f}$ values was due to greater force of interaction between complex and water molecule by forming hydrogen bonding.

The hydration number was increasing with increase in concentration due to strong solute-solvent interaction. There was regular increase in hydration number with increase in concentration in case of [Ni (levo) (1, 10-phenanthroline)] $\mathrm{Cl}$ which indicates the increase in size of secondary layer of hydration i.e. the solvent molecules forms strong co-ordination bond in primary layer. The hydration number in primary layer corresponds to co-ordination number and it is concentration independent. But the hydration number in secondary layer is concentration dependent. So increase in hydration with concentration indicated that water molecules are strongly attached in secondary layer.

Table 2: The Values of Concentration, Apparent Molar Volume $\left(V_{\varphi}\right)$, Limiting Apparent Molar Volume $\left(V_{\varphi}^{0}\right)$ and Experimental Slope $\left(S_{v}\right)$ of $\left[\mathrm{Ni}(\mathrm{Levo})_{2}\left(\mathrm{H}_{2} \mathrm{O}\right)_{2}\right] 2 \mathrm{H}_{2} \mathrm{O}$ and $[\mathrm{Ni}($ Levo $)(1,10-$ Phenanthroline $)] \mathrm{Cl}$ Complexes In Water At 308K.

\begin{tabular}{llll}
$\begin{array}{l}\text { Concentration } \\
(c) \mathrm{mol} \mathrm{dm}^{-3}\end{array}$ & $\begin{array}{l}\text { Apparent molar } \\
\text { vol- } \\
\text { ume }\left(V_{\varphi}\right) \times 10^{3} \\
\mathrm{~m}^{3} \mathrm{~mol}^{-1}\end{array}$ & $\begin{array}{l}\text { Limiting appar- } \\
\text { ent molar vol- } \\
\text { ume }\left(V_{\varphi}{ }^{0}\right)\end{array}$ & $\begin{array}{l}S_{v} \mathrm{~m}^{3} \mathrm{~kg}^{1 / 2} \mathrm{~mol}^{-} \\
\mathrm{m}^{3} \mathrm{~mol}^{-1}\end{array}$ \\
\hline$\left[\mathrm{Ni}(\mathrm{levo})_{2}\left(\mathrm{H}_{2} \mathrm{O}\right)_{2}\right] 2 \mathrm{H}_{2} \mathrm{O}$ & & \\
0.0099 & 0.6083 & & \\
0.0196 & 0.6874 & 0.578 & 0.3443 \\
0.0291 & 0.7530 & & \\
0.0385 & 0.8258 & & \\
0.0477 & 0.8654 & & \\
{$[\mathrm{Ni}($ levo $)(1,10-\mathrm{ph}$ hanthroline $)] \mathrm{Cl}$} & & \\
0.0099 & 0.2332 & & \\
0.0197 & 0.3768 & 0.7265 \\
0.0284 & 0.4681 & & \\
0.0388 & 0.5984 & & \\
0.0481 & 0.6804 & & \\
\hline
\end{tabular}

From Table 2 it was observed that apparent molar volume increased with concentration in both systems indicating the existence of solute-solvent interaction. The value of limiting apparent molar volume and experimental slope were positive in both systems shown by Figure 3 .

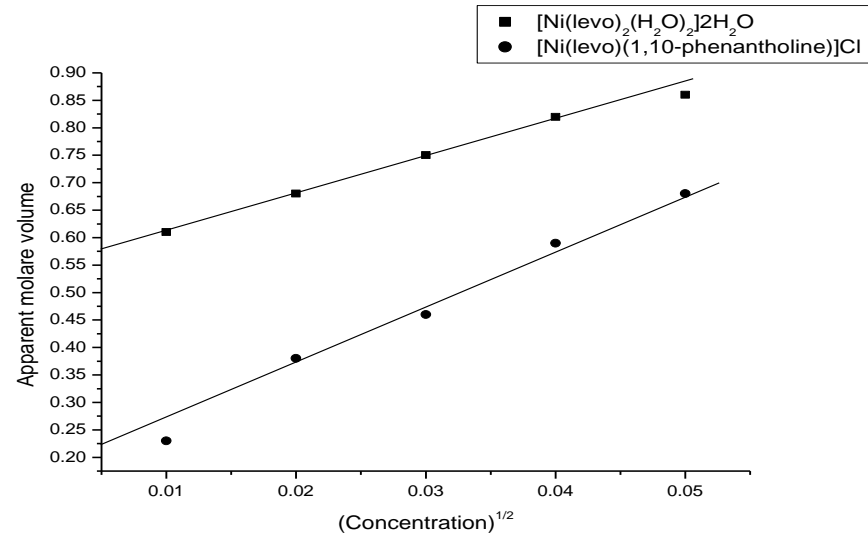

Fig. 3: Variation of Apparent Molar Volume $\left(V_{\varphi}\right)$ with $\mathrm{C}^{1 / 2}$ for $\left[\mathrm{Ni}(\mathrm{Levo})_{2}\left(\mathrm{H}_{2} \mathrm{O}\right)_{2}\right] 2 \mathrm{H}_{2} \mathrm{O}$ and $[\mathrm{Ni}($ Levo $)(1,10-\mathrm{Phenanthroline})] \mathrm{Cl}$ Complexes At $308 \mathrm{~K}$.
It indicates the ion-dipolar interaction in both aqueous solutions. The lower positive value of $S_{v}$ in [Ni (levo) (1, 10phenanthroline)] $\mathrm{Cl}$ indicated strong solute-solvent interaction.

Table 3: The Values of Concentration, Apparent Molar Compressibility $\left(K_{\varphi}\right)$, Limiting Apparent Molar Compressibility $\left(K_{\varphi}{ }^{0}\right)$ and Experimental Slope $\left(S_{k}\right)$ of $\left[\mathrm{Ni}(\operatorname{Levo})_{2}\left(\mathrm{H}_{2} \mathrm{O}\right)_{2}\right] 2 \mathrm{H}_{2} \mathrm{O}$ and $[\mathrm{Ni}($ Levo $)(1,10-$ Phenanthroline)]Cl Complexes In Water At 308K.

\begin{tabular}{llll}
\hline $\begin{array}{l}\text { Concentration } \\
(c) \mathrm{mol} \mathrm{dm}^{-}\end{array}$ & $\begin{array}{l}\text { Apparent molar } \\
\text { compressibility } \\
\left(K_{\varphi}\right) \times 10^{3}\end{array}$ & $\begin{array}{l}\text { Limiting appar- } \\
\text { ent molar com- } \\
\text { pressibility } \\
\left(K_{\varphi}{ }^{0} \mathrm{~mol}^{-1}\right.\end{array}$ & $\begin{array}{c}S_{k} \mathrm{~m}^{3} \mathrm{~mol}^{-1} \mathrm{~kg}^{1 / 2} \mathrm{~mol} \\
3 / 2\end{array}$ \\
\hline$\left[\mathrm{Ni}(\text { levo })_{2}\left(\mathrm{H}_{2} \mathrm{O}\right)_{2}\right] 2 \mathrm{H}_{2} \mathrm{O}$ & & \\
0.0099 & 1.9801 & & \\
0.0196 & 2.3523 & 1.832 & \\
0.0291 & 2.7682 & & \\
0.0385 & 3.0297 & & \\
0.0477 & 3.4035 & & \\
{$[\mathrm{Ni}($ levo $)(1,10-\mathrm{phenanthroline})] \mathrm{Cl}$} & & \\
0.0099 & 1.6550 & & \\
0.0197 & 1.8621 & & \\
0.0284 & 2.1233 & & \\
0.0388 & 2.3381 & & \\
0.0481 & 2.5901 & & \\
\hline
\end{tabular}

The value of apparent molar compressibility $\left(K_{\varphi}\right)$ was increased with increase in concentration in both systems shown Table 3 . It shows strong electrostatic attractive force in the vicinity of ions. It may be concluded that strong molecular association was found in [Ni (levo $\left.)_{2}\left(\mathrm{H}_{2} \mathrm{O}\right)_{2}\right] 2 \mathrm{H}_{2} \mathrm{O}$ with higher positive $K_{\varphi}$ values.

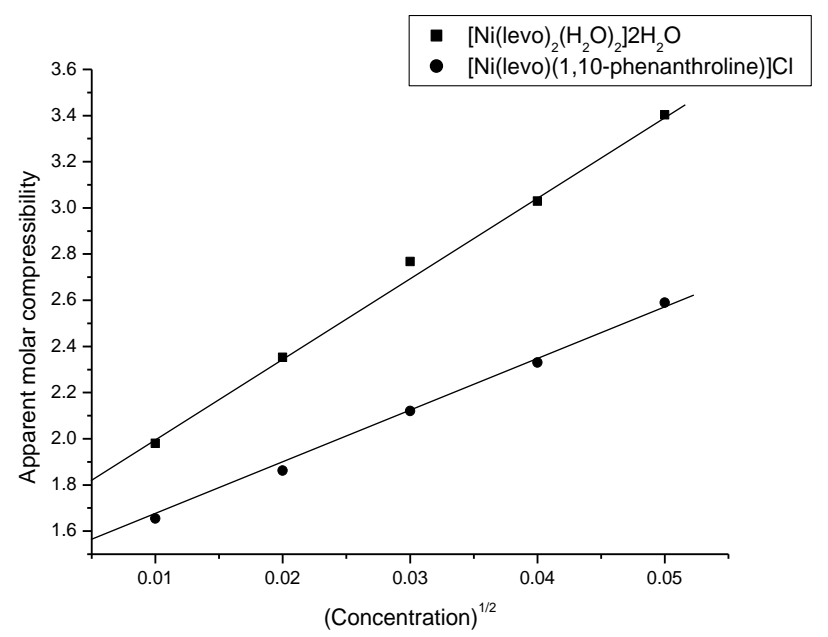

Fig. 4: Variation of Apparent Molar Compressibility $\left(K_{\varphi}\right)$ with $\mathrm{C}^{1 / 2}$ For $\left[\mathrm{Ni}(\text { Levo })_{2}\left(\mathrm{H}_{2} \mathrm{O}\right)_{2}\right] 2 \mathrm{H}_{2} \mathrm{O}$ and $[\mathrm{Ni}($ Levo $)(1,10$-Phenanthroline $)] \mathrm{Cl} \mathrm{Com}-$ plexes $308 \mathrm{~K}$.

The value of $K_{\varphi}^{0}$ and $S_{k}$ were obtained in Figure 4. The higher positive $K_{\varphi}^{0}$ and $S_{k}$ value also indicates strong solute-solute interaction. The solute-solvent interaction is enhanced with chelation.

\section{Conclusion:}

Acoustical and volumetric properties of aqueous solutions of [ $\mathrm{Ni}$ (levo) $\left.{ }_{2}\left(\mathrm{H}_{2} \mathrm{O}\right)_{2}\right] 2 \mathrm{H}_{2} \mathrm{O}$ and [Ni (levo) $(1,10$-phenanthroline)] $\mathrm{Cl}$ at $308 \mathrm{~K}$ was studied. From the experimental data solute-solvent and solute-solute interaction were studied. It was concluded that there was weak solute-solvent interaction in [ $\mathrm{Ni}$ (levo) $\left.{ }_{2}\left(\mathrm{H}_{2} \mathrm{O}\right)_{2}\right] 2 \mathrm{H}_{2} \mathrm{O}$ system and strong solute-solvent interaction in [Ni (levo) $(1,10-$ phenanthroline)] $\mathrm{Cl}$ system. 


\section{Acknowledgement}

The authors are thankful to PG Dept. of Chemistry, Raven Shaw University for providing facilities to carry out this work.

\section{References}

[1] Jadav SS, Singh YP \& Ragkumar J (1999), J. Ind. Coun. Chem., 16, 20.

[2] Bhatt SC, Semwal H, Lingwal V, Singh K \& Semwal BS (2000) Acoustical parameters of some molecular liquids. J. Acous. Soc. India, 28, 293-296

[3] Verma RP and Kumar S (2000) Ultrasonic velocity and density measurements of ammonium soaps in 2-propanal. Ind. J. pure and appl. Phy., 38, 96-100.

[4] Kalidos M and Ravi S (2002) new method of determining the structure factor of real liquids and their mixtures using ultrasonic velocity. Statistical Mechanics and its Application, 312, 59-69.

[5] Govindrajan S, Kannapan V \& Ramesh MD (2003) Ultrasonic studies on the molecular interaction of gallic acid in aqueous methanol and acetone solutions and the role of gallic acid as viscosity reducer. J. Mol. Liq., 107, 289-316.

[6] Patil KJ, Dagade DH (2004) Studies of molecular interactions in aqueous and $\mathrm{CCl} 4$ solutions involving 18 -crown- 6 by application of Kirkwood-Buff theory. J. Chem. Thermodyn., 36, 677-682.

[7] Kamila S, Jena S \& Bihari B (2005) Studies on thermo-acoustic parameters in binary liquid mixtures of phosphinic acid ( Cyanex 272) with different diluents at temperature $303.15 \mathrm{~K}$ : an ultrasonic study. J. Chem. Thermodyn., 37, 820-825.

[8] Awasthi A, Sukla JP \& Rastogi M (2004) Ultrasonic and IR study of molecular association process through hydrogen bonding in ternary liquid mixtures. Fluid Phase Equil. 215, 119-127.

[9] Abraham R, Abdulkhadar M, Ashokan CV (2000) Ultrasonic investigation of molecular interaction in binary mixtures of nitriles with methanol/toluene. J. Chem. Thermodyn., 32, 1-16.

[10]Mishra A, Vibhu I, Singh R, Gupta M \& Sukla JP (2007) Acoustic, viscometric and optical properties of binary mixtures of tetrahydrofuran with 1-propanol and 2-propanol. Physics and Chemistry of Liquids, 45, 93-104.

[11]Ali A, Nain AK, Chand D \& Lal D (2007), Ultrasonic, volumetric and viscometric studies of molecular interactions in binary mixtures of dimethylsulphoxide with polar substituted cyclohexanes at $30^{\circ} \mathrm{C}$ Physics and Chemistry of Liquids, 45, 79-91.

[12]. Eqbal M \& Verrall RE (1989) apparent molar volume and adiabatic compressibility studies of aqueous solutions of some drug compounds at 250C. Canadian Journal of Chemistry, 67, 727-735.

[13]Jayamadhuri N, Naidu PS \& Prasad KR (2012) Ultrasonic Velocity, Density and Viscosity Studies in the Aqueous Solutions of Hydrate Compounds. Research Journal of Pharmaceutical, Biological and Chemical Sciences, 3, 861-875.

[14]Fish DN, Chow AT (1997) the clinical pharmacokinetics of levofloxacin. Clin. Pharma. Cokineto. 32, 101-119.

[15]Mendoza G, Martinez LMR, Alonso RP, Solons X \& Esparza RM ( 1987) Synthesis and characterization of mixed ligand complexes of copper with nalidixic acid and $(\mathrm{NN})$ donors, crystal structure of $\left.\mathrm{Cu}(\mathrm{Phen})(\mathrm{NaI})-\left(\mathrm{H}_{2} \mathrm{O}\right)\right] \mathrm{NO}_{3} .3 \mathrm{H}_{2} \mathrm{O}$. Inorganic Chimica Acta., 138, 41 47.

[16]Diez GM \& Panner KH (1993), some mixed-ligand complexes of copper (II) with drugs of the quinolone family and (NN) donors. Crystal structure of $\left[\mathrm{Cu}\right.$ (phen) $\left.(\mathrm{Cnx})\left(\mathrm{H}_{2} \mathrm{O}\right)\right] \mathrm{NO}_{3} \cdot \mathrm{H}_{2} \mathrm{O}$. Journal of Inorganic Biochemistry, 50, 65-78.

[17]Wallis SC, Gahan LR, Charles BG, Hambley TW \& Duckworth PA (1996) Copper(II) complexes of the fluoroquinolone antimicrobial ciprofloxacin. Synthesis, X-ray structural characterization, and potentiometric study. Journal of Inorganic Biochemistry, 62, 1-16.

[18]Diaz GM, Alonso RP, Esparza RM.( 1996). Stability constants of copper (II) mixed complexes with some 4-quinolone antibiotics and (N-N) donors. Journal of Inorganic Biochemistry, 64, 207-214

[19]Turel I. (2002) the interaction of metal ions with quinolone antibacterial agents. Coord. Chem Rev, 232, 27-47.

[20]Sakurai M, Nakawaga T.( 1984) Densities of dilute solutions of water in n-alkanols at $278.15,288.15,298.15,308.15$, and $318.15 \mathrm{~K}$ Partia molar volumes of water in n-alkanols. J. Chem Thermodynamics, 16 , 171-174.

[21]Imran M, Kokab T, Latif S, Liviu M, Mohmood.(2010) Characterization and in vitro Antibacterial Studies of Complexes using Quinoline Antibiotics as Primary Ligand. J. Chem Soc. Pak., 32, 223-228.
[22]Harned HS, Owen BB (1958) The Physical chemistry of electrolyte solutions, 3rd Edn.Reinhold, Newyork.p- 358.

[23]Masson DO (1929) Solute molecular volumes in relation to solvation and ionization. Phil. Mag, 8, 218-235.

[24]Dash UN \& Supakar S (1929) Acoustic letters, 16, and 135.

[25] Wood AB (1960) A Text Book of sound, 3rd Edn. (G. Bell, London), p. $51 \& 577$.

[26]Gucker FT (1933) the Apparent Molal Heat Capacity, Volume, and Compressibility of Electrolytes. Chem. Rev., 13, 111-130.

[27]Debye P \& Huckel E (1932) the theory of electrolytes. I. Lowering of freezing point and related phenomena. Physik. Z., 24, 185-206.

[28]Passynsky A (1938) Actaphysicochim, 8, 357.

[29] Ramasami P \& Kakkar R (2006) Partial molar volumes and adiabatic compressibilities at infinite dilution of aminocarboxylic acids and glycylglycine in water and aqueous solutions oaf sodium sulphate at (288.15, 298.15 and 308.15) K. J. Chem. Thermodyn, 38, 1385-1395.

[30]Bansal KR (1990) a text book of organic chemistry, 2nd ed. (Willey Estern ltd, New Delhi), p-477.

[31]Panday JD, Shukla A, Rai RD \& Mishra KJ (1989) Ultrasonic, volumetric and viscometric studies of tetracycline and its allied compound. J. Chem. Eng. Data, 34, 29-31. 